\title{
Constitutional Skepticism and Local Facts
}

Louis Michael Seidman

Georgetown University Law Center, seidman@law.georgetown.edu

This paper can be downloaded free of charge from:

https://scholarship.law.georgetown.edu/facpub/2391

https://ssrn.com/abstract=3878321

Forthcoming in European Constitutional Law Review.

This open-access article is brought to you by the Georgetown Law Library. Posted with permission of the author. Follow this and additional works at: https://scholarship.law.georgetown.edu/facpub

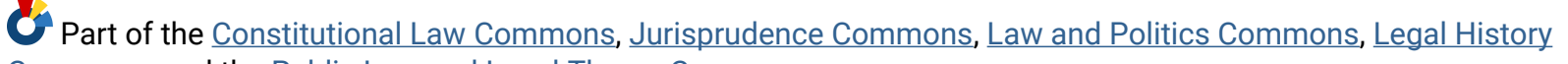
Commons, and the Public Law and Legal Theory Commons 


\title{
Constitutional Skepticism and Local Facts
}

\author{
Louis Michael Seidman*
}

BRIAN Christopher JONeS, Constitutional Idolatry and Democracy: Challenging the Infatuation with Writtenness (Edward Elgar Publishing Limited 2020) 210 pp English

Do written constitutions matter? In his important and provocative book about written constitutions, Brian Christopher Jones seems to say "not much." He takes constitutional idolatry as his target and defines it as "drastically and persistently over-selling the importance and effects of written constitutions" (P. 5, emphasis in original). Idolatry of this sort, he warns, "turns [constitutions] into false gods of our legal, political and societal communities." (P. 11)

But it quickly becomes apparent that Jones is not saying quite what he means. If written constitutions aren't very important, then they cannot be very evil, and Jones seems to think that their potential for evil is quite large. That potential is central to his opposition to the movement in the United Kingdom favoring the creation of an integrated, written constitution an opposition that motivates the book.

Most of the book consists of a detailed argument that written constitutions produce serious pathologies that the United Kingdom and the handful of other outlier nations without written constitutions have so far avoided. That claim is hard to reconcile with the assertion that constitutions don't make much difference. Although stated in an unnecessarily misleading way, his real argument seems to be not that constitutions don't matter, but that they don't matter in the way their proponents think they do. They do not lead to the good outcomes

\footnotetext{
* Carmack Waterhouse Professor of Constitutional Law, Georgetown University Law Center. My thanks to Yvonne Tew and Mark Tushnet for comments on an earlier draft of this review.
} 
claimed for them, but instead degrade otherwise well-functioning political systems. His work is therefore best interpreted as part of a growing if still nascent movement toward constitutional skepticism.

I count myself as a constitutional skeptic, at least in the American context. I think that the American constitution has mattered, and that as it operates today, it matters for the worse. It is therefore not surprising that I find many of Jones' arguments about constitutional pathologies powerful and convincing. Still, his misleading definition of constitutional idolatry forces readers to ask questions about whether Jones's initial formulation is right. Do written constitutions really matter and, if so, how, when, and why?

Because Jones works within the rapidly expanding, overlapping fields of comparative and empirical constitutionalism, he often tries to answer these questions using large-n empirical studies of constitutions around the world. I am more skeptical than he is of the urge to generalize embedded within this methodology. Surely, the answers turn at least in part on what kind of constitution we are talking about. A constitution that permanently entrenches the power of a "dear leader" produces tendencies different from a constitution that provides for regular rotation in office. Constitutions that are easy to amend or that prohibit or limit judicial review may pose fewer problems than constitutions that are deeply entrenched or that label judges as special constitutional guardians.

Beyond the contents of a constitution, much will depend on how the document interacts with particular constitutional cultures at particular moments in a nation's history. It matters, for example, whether a political culture views its constitution as an object of reverence 
and disparagement of it as blasphemy, or whether it views its constitution as an imperfect and temporary settlement subject to criticism and change.

It also matters how a constitution is located within a nation's history and how it interacts with political and social forces at a particular moment in time. The creation of a new constitution in South Africa might, at least for a while, symbolize the vibrant and hopeful emergence of a new order, ${ }^{1}$ while enforcement of ancient provisions entrenched in the American Constitution might reflect the last gasp of a dying regime. ${ }^{2}$ The structural safegards embedded the the Weimar constitution were far less effective than structural safegards in the constitutions of more successful democracies, ${ }^{3}$ and even extensive and admirable parchment rights in the constitutions of authoritarian countries are not effective at all. ${ }^{4}$ At least for a time, the Pakistani Supreme Court used the country's constitution to rally opposition to autocracy, ${ }^{5}$ but Hungary's constitution has been amended in ways that entrench an autocratic government. $^{6}$

Moreover, if one insists on generalizing, then narrower generalizations based on types of constitutional provisions may be more fruitful than lumping together all provisions of all

1 See e.g., John B. Attanasio, Foreword: Freedom, 41 St. L. U. L. J. 1243 (1997) (hailing the South African Constitution).

2 See, e.g., Robin West, The Aspirational Constitution, 88 N.W.U. L. Rev. 241, 247 (1993) (“More often than not, [the American] adjudicated Constitution has served to protect existing distributions of social, economic, racial, sexual, linguistic, and cultural power against serious threat of change.")

3 For an account of the collapse of the Weimar constitutional regime tied to flaws in constitutional design, see Peter L. Lindseth, The Paradox of Parliamentary Supremacy, Delegation, Democracy, and Dictatorship in Germany and France, 1920s-1950s, 113 Yale L. J. 1341, 1361-74 (2004).

$4 \quad$ See, e.g., Thomas E. Towe, Fundamental Rights in the Soviet Union, 115 Pa. L. Rev. 1251, 1251 (1967) (noting that the Soviet constitution protected many of the same right same rights as the American constitution, but that the protections were ineffective).

5 See Yvonne Tew, Strategic Judicial Empowerment, __Amer, J. Comp. L. ___ (2021) (forthcoming). 6 See Timea Drino zi \& Aghieszka Bien-Kacala, Illiberal Constitutionalism: The Case of Hungary and Poland, 20 German L. J. 1140 (2019). 
written constitutions. It is helpful to make distinctions along two overlapping dimensions:

between rights-protecting provisions and structural provisions, and between rule-like provisions and standard-like provisions.

Rights-protecting provisions tend to matter less than structural provisions. For example, there is no evidence that countries that constitutionally prohibit torture engage in the practice less frequently than countries that don't. ${ }^{7}$ More generally, countries with extensive bills of rights don't seem to fare better in protecting civil liberties than countries without these protections. $^{8}$

On the other hand, structural provisions can matter quite a lot. ${ }^{9}$ Parliamentary systems where a party need win only one election to implement its program may produce very different outcomes from presidentialist systems where a party must prevail in separate executive and legislative elections to assert real power. Proportional representation empowers groups different from those empowered by first-past-the-post elections and has different implications for the formation of political parties and for the stability of governing coalitions.

Similarly, rule-like provisions may be more effective in resolving disputes than standardlike provisions. The American constitutional rule that presidential elections occur every four years has been regularly and uncontroversially obeyed for centuries. ${ }^{10}$ The American

$7 \quad$ See Adam S. Chilton \& Mila Versteeg, The Failure of Constitutional Torture Prohibitions, 44 J. Legal Stud. 417 (2015).

8 As noted above, the Constitution of the Soviet Union featured an extensive bill of rights but provided little actual protection for them. See note 4, supra. Jones notes (P. 125) that Australia has no bill of rights, but, according to Freedom House, has the third highest ranking in the world for rights protection.

$9 \quad$ See generally Mark V. Tushnet, Why the Constitution Matters (2010).

10 Even here, though, it is a mistake to generalize in a fashion that abstracts from different local circumstances. In other countries, rules limiting the tenure of executives have sometimes failed. See generally, Mila Versteeg, Timothy Horley, Anne Meng, Marica Guim \& Marilyn Guirguis, The Law and Politics of Presidential Term Limit Evasion, 120 Colum L. Rev. 173 (2020). 
constitutional standard that all persons are entitled to due process of law has given rise to inconsistent, shifting, and deeply controversial outcomes that have left virtually no one satisfied.

All of this leads to a doubt about whether broad generalizations are useful in this field. Because of that doubt, I have tried to be careful in my own work to confine my arguments to the American constitutional experience. ${ }^{11}$ Still, I am open to the possibility that if one is careful to qualify and contextualize one's conclusions, one may be able to identify some narrower tendencies, even if the tendencies are sometimes counterbalanced by particular facts and circumstances.

Jones identifies two overlapping tendencies that he associates with written constitutions. First, by their very nature, written constitutions tend to limit democratic engagement. Because constitutions are entrenched, they take some issues off the agenda for open democratic contestation. Because they are frequently enforced by judges, they substitute paternalistic, elite political morality for majority rule.

Second, written constitutions discourage what Jones labels "constitutional maintenance" - the ordinary, gradual, and continual updating of government structures to reflect current conditions and desires. By hard wiring these structures, written constitutions either prevent change entirely or give way to change only in occasional, convulsive, and disruptive "constitutional moments."

11 See, e.g., Louis Michael Seidman, From Parchment to Dust: The Case for Constitutional Skepticism (2021) (forthcoming); Louis Michael Seidman, On Constitutional Disobedience (2012). 
I believe that both these claims are correct if they are understood as tendencies, rather than iron laws. Still, a more particularistic approach might have led Jones to expand, qualify, and defend his conclusions in ways that are not fully realized in this short book. The rest of this review is devoted to advancing that project.

Consider first the question of democratic engagement. Jones's generalization is subject to several qualifications rooted in distinctions that I have already mentioned. Most obviously, the truth of his claim rests on what particular constitutions say.

The framers of America's constitution set out to limit democratic engagement. They believed that the people's voice needed to be filtered through institutions dominated by elites, and they established a byzantine system of veto gates, indirect representation, overlapping jurisdictions, and divided electorates to frustrate popular control. In later years, several constitutional amendments have expanded the franchise and created more democratic accountability. But it remains true that the United States must live with the unfortunate consequences of the Framers' original decisions. In contrast, different constitutional arrangements establishing different structures might facilitate rather than discourage democratic engagement.

The truth of Jones' thesis will also depend on how deeply a constitution is entrenched and, conversely, how sclerotic ordinary political processes have become. Constitutional provisions that are difficult or impossible to amend eliminate topics from political debate, but if provisions can easily be amended, they may put issues on the agenda rather than take them off. Similarly, if as a practical matter tradition, habit, or the maldistribution of political and cultural power make it difficult or impossible to repeal or amend ordinary legislation, the anti- 
democratic tendency of constitutions matters less. To put the same point slightly differently, the very definition of "constitution" turns on questions of degree rather than kind. In different polities, different rules are more or less entrenched. Under modern conditions, the United States Constitution is almost impossible to amend, ${ }^{12}$ but countries like India ${ }^{13}$ and Malaysia ${ }^{14}$ permit amendments by a two-thirds legislative majority, a threshold that is much more within reach. The more a constitution looks like an ordinary statute, or the more ordinary statutes look like a constitution, the less serious the worry about limiting democratic engagement. We must also consider whether constitutional provisions are enforced by some form of strong judicial review. Judicial enforcement of constitutional provisions limits democratic engagement, but constitutions that rely on political enforcement can make constitutional values the subject of democratic contestation rather than an escape from it.

This qualification must, itself, be qualified. It may seem to confound questions about constitutional obligation with questions of how that obligation is enforced. So long as there is constitutional obligation, one might respond, political actors will be duty-bound to obey constitutional requirements even if no judge will order them to do so. And to the extent that these political actors do their duty, the space for political contestation will still shrink, albeit

\footnotetext{
12 Amendments must be proposed by a resolution approved by two thirds of the members of both Houses of Congress or, on application of two thirds of the States, by a constitutional convention. Whichever method is used, the proposed amendment is not ratified unless thereupon approved by three fourths of the states. See United States Constitution, Art V. Since 1789, the American Constitution has been amended only twenty-seven times. The last successful amendment was part of the original Bill of Rights submitted to the states in the eighteenth century. It gradually gained state support until it was finally declared ratified in 1992 . The last successful amendment to be ratified entirely in modern times occurred in 1971.

13 See India's Constitution of 1949 with Amendments through 2015, Part XX, §316, https://www.constituteproject.org/constitution/India 2015.pdf?lang=en (last visited June 17, 2021).

$14 \quad$ See Malaysia's Constitution of 1957 with Amendments through 2007, Eighth Schedule, Part $1 \S 19$, https://www.constituteproject.org/constitution/Malaysia 2007.pdf?lang=en (last visited June 17,2021).
} 
because of naked constitutional obligation itself rather than because of judicial enforcement of the obligation.

But at this point, the distinction between rule-like and standard-like constitutional provisions takes hold. A rule - say the requirement that presidents be elected every four years - binds political actors and, so, even without judicial enforcement, eliminates political contestation so long as the actors obey the rule. A standard - say, the requirement that persons be accorded due process of law -- is open to different, plausible interpretations. If judges are not authoritative interpreters, then these different interpretations remain topics open to political contestation.

Matters are further complicated by another particularistic detail - the mode of constitutional interpretation dominant in a constitutional culture. Opponents of democracy sometimes use constitutional interpretation to turn standards into rules. For example, in American constitutional culture, constitutional originalists claim that they can limit the range of plausible interpretations of standards by binding us to original understandings at the time the language was written. Originalism, at least as practiced in America, ${ }^{15}$ tends to frustrate democratic engagement in two separate ways. First, as just mentioned, it often attempts to turn contestable standards into clear rules by reference to decisions supposedly made by past generations. Second, it tends to deflect argument from relevant modern policy concerns to deeply irrelevant questions about linguistics, grammar, and original public meaning. In contexts like the United States, where originalism is powerful, these two features work together to provisions more open to contemporary contestatation. See Jamel Green \& Yvonne Tew, "Comparative Approaches to Constitutional History" in Erin Delany \& Rosaland Dixon, Comparative Judicial Review (2018). 
constrain the right of people to rule themselves. In much of the rest of the world, where originalism does not dominate or takes different forms, the problem is less serious.

Conversely, other modes of interpretation can turn rules into standards. For example, the "margin of appreciation" doctrine can soften the force of rules and, so, open up room for democratic debate. Similarly, some forms of "living constitutionalism" prevalent in the United States require less rigid and more contestable readings of constitutional rules.

None of this is to say that constitutional rules are always evil. Much depends on whether we are talking about structures or rights. Constitutional structures can facilitate rather than obstruct politics. They are necessary to get politics off the ground. Moreover, rulelike structures are usually preferable to standard-like structures. Popular control is hindered rather than helped if there is argument every four years over whether the sitting president really must relinquish power, and a rule sometimes prevents these arguments from arising. ${ }^{16}$ In contrast, rules about rights tend to restrict politics. They take issues off the table. But standard-like rights can have the opposite effect. The task of giving meaning to the standards can serve as a locus for popular mobilization and debate. Hence, a preference for rule-like structures, but standard-like rights.

Taken together, these qualifications take some of the sting out of Jones's argument against written constitutions. It turns out that his claim is true regarding some constitutions but not others. To summarize: First, if the constitution is not deeply entrenched, it might itself become a subject for political contestation. Second, even deeply entrenched constitutions can be opened up by less rigid forms of constitutional interpretation. Third ambiguous, or open-

16 But see note 10, supra. 
textured rights-protecting standards can motivate rather than permanently resolve political controversy, at least if they are not liquidated by originalist methodology or by strong forms of judicial review. Finally, clear structural rules may provide space for political argument, rather than shutting it down. (Of course, this conclusion itself must be particularized. Structural rules that are antidemocratic - the structure of the United States Senate comes to mind - may sharply limit political argument). Because of his insistence on generalization, Jones may have missed these possibilities.

Beyond all this, there is another, deeper difficulty with Jones' argument from democracy. He points out that many modern constitutions, following the model of the American preamble, purport to speak for "We the people." He argues that this declaration is a sham, hiding the fact that constitutions often privilege "We the judges" or "We the dead people" over ordinary, living people. But the argument depends on a rejection of what might be called the Heisenberg Political Uncertainty Principle: The voice of the people cannot be disentangled from the method used to discern it. If the Principle holds, then, pace Jones, we cannot identify a pure voice of the people that is independent of the structures that record and measure it.

Consider in this regard John Marshall's initial defense of written constitutionalism in Marbury v. Madison:

the people have an original right to establish, for their future government, such principles as, in their opinion, shall most conduce to their own happiness. ... The exercise of this original right is a very great exertion; nor can it, nor ought it, to be frequently repeated. The principles, therefore, so established, are deemed fundamental. And, as the authority from which they proceed is supreme, and can seldom act, they are designed to be permanent. ${ }^{17}$ 
Marshall unwittingly invokes the Uncertainty Principle by pointing out that the voice of the people when measured by their constitutional decisions can differ from the voice of the people when measured by ordinary political mechanisms. For Marshall, privileging the people's constitutional voice vindicates rather than frustrates popular sovereignty. Just because "the people have an original right" to rule themselves, we are bound to respect their voice when they exercise that right by promulgating a written constitution.

Unfortunately, though, Marshall failed to reckon with the fact that popular sovereignty is a zero-sum game. Put differently, he failed to understand the full, destabilizing force of the Uncertainty Principle. If the content of popular will is irreducibly dependent on how it is measured, then any method of measuring it will produce "distortions." (The scare quotes are meant to indicate that there is no antiseptic baseline state from which distortions can be measured). Protecting the right of some people to establish a constitution means disregarding the right of other people who are forced to live under constitutional arrangements that they never endorsed.

Marshall attempted to resolve the problem with the observation that " $[\mathrm{t}]$ he exercise of this original right is a very great exertion; nor can it, nor ought it, to be frequently repeated."18 Perhaps there is something to that assertion, but taken by itself, it is subject to an obvious objection. Exercising "the original right" requires great exertion only because those exercising it are attempting to bind their nation "for ages to come,"19 to use some more of Marshall's

$18 \quad$ Id.

19 M'Culloch v. Maryland, 17 U.S. 316, 415 (1819). 
rhetoric. If one has more modest ambitions - to establish structures that might be useful for a while but are subject to easy revision - then the task is much less arduous and there is no apparent reason why it cannot be "frequently repeated."

Almost two centuries later, Bruce Ackerman offered a sophisticated and influential elaboration on Marshall's point that made it more convincing. ${ }^{20}$ Ackerman argued that during ordinary periods, the notion that "the people" rules amounts to democratic romanticism. Relying on a generation of political science research, he pointed out that ordinary politics is dominated by well-organized special interests that do not speak for the people. The average citizen is ignorant of and disengaged from political issues.

Fortunately, though, ordinary politics is not the only kind of politics that nations experience. Ackerman believed that there are also rare but important "constitutional moments" when the people awaken from their slumber. In his initial formulation, Akerman identified three American moments: The founding period when the original constitution was drafted; the Reconstruction period following the civil war; and the New Deal period when Franklin Roosevelt revolutionized the American government. In later work, he added the civil rights era in the mid-twentieth century to the list. ${ }^{21}$ On Ackerman's account, these are periods when "the people" pay attention, mobilize, and decide on their future. Popular sovereignty amounts to a requirement that these truly democratic decisions be obeyed during periods of ordinary politics. 
A more complete defense of Jones's position would require responding to Ackerman's argument. There are available responses. Ackerman may overstate the extent to which constitutional moments differ from ordinary times. The problem is most acute with regard to the American founding, during which "the people" were conceptualized in a way that excluded women, people of color, and most people who did not own property. Even if we ignore this glaring defect, modern scholarship has demonstrated that the struggle over ratification was dominated by backroom deals, special interest politics, and outright violence and coercion. ${ }^{22}$ Similarly, the Republicans who drove Reconstruction were not immune from cynical political calculation. Some favored voting rights for African Americans in the south, where their votes were necessary to secure a Republican majority, but not in the north, where their votes might disrupt a racial hierarchy. ${ }^{23}$ Yes, Franklin Roosevelt won huge popular majorities at least in the beginning of his presidency and succeeded in remaking constitutional law for several generations. But his success was the product of his skillful melding of a coalition among various special interest groups - a coalition that disgracefully disregarded the interests of African Americans. ${ }^{24}$

Ackerman may also have underestimated the extent to which voters and politicians respond to constitutional concerns even during periods of ordinary politics. Constitutional debate is not confined to periods of crisis. Of course, Ackerman is right that we should not romanticize this debate. Popular ignorance and uninterest during ordinary times are real

22 See generally Michael Klarman, The Framers' Coup: The Making of the United States Constitution (2016); Woody Holton, Unruly Americans and the Origins of the Constitution (2007).

23 See William E. Nelson, The Fourteenth Amendment: From Principle to Judicial Doctrine, 46, 57-58 (1988) (noting Republican fear of losing control of Congress and that section 2 of the Fourteenth Amendment might be read to authorize denial of black franchise).

24 See Ira Katznelson, Fear Itself: The New Deal and the Origin of Our Time 17-18 (2013). 
problems. Still, we need to make comparative judgments. Ignoring the will of voters and politicians means empowering judges, and we should not romanticize them either. Even if decisions made during constitutional moments deserve special respect, we are still left with the problem of how to interpret the decisions and who should do the interpreting. There is no good reason to believe that unelected judges resolving constitutional disputes will be faithful agents who will merely implement popular will. Judges themselves represent an interest group, often a highly privileged one. Ackerman fails to explain why granting judges final interpretive authority is preferable to leaving the matter to ordinary, albeit concededly flawed, political processes.

For these reasons, Jones may be right when he insists that written constitutions limit democratic engagement, but the argument is more complex and fraught than he acknowledges.

What about the problem of constitutional maintenance? His argument here is more developed and convincing. One can concede the importance of structural rules that channel and facilitate politics without insisting that the rules should be changed only in convulsive, constitutional moments. He argues that as circumstances and norms evolve, rules should change gradually to reflect new realities. There is no reason to wait for occasional moments of crisis to modernize them.

Jones certainly has a point, but here, too, his argument needs to be qualified and contextualized. First, he overemphasizes the extent to which constitutional rules are entrenched. Sometimes, constitutional rules are simply ignored, perhaps because they are impractical, counterproductive, or merely silly. For example, since the founding of the American Republic, seemingly clear constitutional rules requiring six-year terms for Senators 
from newly admitted states ${ }^{25}$ and mandating that constitutional amendments be presented to the President for his signature or veto ${ }^{26}$ have been ignored.

Moreover, it is not true that other rules are impervious to amendment during times of ordinary politics. Even though the American constitution is deeply entrenched, there have been occasional amendments in ordinary times that have changed the rules of the game. ${ }^{27}$ More significantly, the very fact that that the formal constitution is difficult to change has led the United States Supreme Court to revise the rules in significant ways. Without the benefit of constitutional amendment, the Supreme Court has created out of whole cloth rights to abortion ${ }^{28}$ and gay marriage. ${ }^{29}$ It has manufactured limits on the federal spending power ${ }^{30}$ and on Congress's power to structure administrative agencies. ${ }^{31}$ It apparently stands ready to greatly increase the power of organized religion. Jones's real complaint about this process is not that it fails to maintain the constitution, but that it fails to do so through democratic politics.

25 Art. I, §3, cl. 1 and the Seventeenth Amendment of the United States Constitution both state that senators shall serve "for six years." But ever since Vermont was admitted as the fourteenth state, Congress has provided that one of the new senators would serve for less than six years so as to prevent both senators from standing for reelection in the same year.

26 Art. I, §7, cl. 3 of the United States Constitution provides “Every order, Resolution, or Vote to Which the Concurrence of the Senate and House of Representatives may be necessary (except on a question of Adjournment) shall be presented to the President of the United States; and before the Same shall take Effect, shall be approved by him, or being disapproved by him, shall be repassed by two thirds of the Senate and House of Representatives, according to the Rules and Limitations prescribed in the Case of a Bill." Resolutions proposing constitutional amendments require the concurrence of the Senate and House of Representatives, but with the exception of the Thirteenth Amendment abolishing slavery, they have never been presented to the President for his signature.

$27 \quad$ For example, the Seventeenth Amendment provided for the direct election of Senators, the Nineteenth Amendment extended the rights to vote to women, and the Twenty-sixth Amendment extended the right to vote to people eighteen years and older.

28 See Roe v. Wade, 410 U.S. 113 (1973).

$29 \quad$ See Obergefell v. Hodges, 135 S. Ct. 2584 (2015)

30 See National Federation of Independent Business v. Sebelius, 567 U.S. 519, $579-86$ (2012).

31 See Free Enterprise Fund v. Public. Company Accounting Oversight Board, 561 U.S. 477 (2010). 
A second qualification concerns the importance of the rule at issue. For many issues classically the question of which side of the road motorists should drive on - it is better to settle the matter one way or the other than to engage in endless struggle about settling it the "right" way. (I will leave to the reader whether to treat this assertion as a bad pun revealing an anti-UK bias). Perhaps four years is not the optimal length for presidential terms, but it is better to definitively resolve the issue than to engage in endless argument designed to get to the right result. In cases like these, the fact that constitutional entrenchment that takes the issue off the table may be a virtue rather than a vice.

On the other hand, the side-of-the-road example might be taken to cut the other way. I know of no country where this rule is constitutionally entrenched, but I know of no country where governments are paralyzed by continuing argument about it. The very fact that settlement is important may provide sufficient impetus for ending the argument without constitutional entrenchment.

Moreover, there are other rules that are less arbitrary and where entrenchment is therefore more controversial. In the United States, entrenched rules relating to apportionment of representation in the Senate and the election of presidents matter a great deal. The entrenchment of these rules does serious harm.

What is needed, then, is a balance between the need for settlement through constitutional entrenchment and the need for flexibility that allows for reform. When settling the matter one way or the other is more important than settling it the right way and when there will otherwise be temptation to destabilize the rule, constitutional entrenchment may serve a useful purpose. When the content of the rules really matters and obstruct good 
governance, then entrenchment is an evil. Of course, people will have reasonable disagreements about which category is appropriate for various rules - a disagreement that suggests that the degree of entrenchment, itself, ought not be entrenched.

That disagreement, in turn, leads to a final worry about generalizations. The rules entrenched by constitutions work, if they work at all, only when the stakes of politics are relatively low. So long as the winner of the next election does not pose an existential crisis, people are more likely to see constitutional structures as necessary, even if suboptimal, rules of the road. They can be expected to abide by the rules, live with their fears, and postpone their ambitions in the expectation of better times ahead.

Things are radically different when elections really matter. If the very existence of the country turns on who wins, then the arbitrariness or unfairness of rules that produce the "wrong" result is harder to ignore. In a world like this, constitutions either don't matter or matter in all the wrong ways. They don't matter because no written text will constrain people faced with existential threats. They matter in the wrong ways because in a polarized political culture, both sides will seize upon constitutional rhetoric that inflames passions without resolving disputes.

These observations, in turn, provide the best argument for Jones' thesis, although it is an argument that he fails to make. Instead of uniting countries, constitutions work best in countries that are already united. When countries are riven disagreement, focus on constitutions can lead to a total unravelling. ${ }^{32}$

32 For multiple examples illustrating the point, see Hanna Lerner, Making Constitutions in Deeply Divided Societies (2011); Asli Bali \& Hanna Lerner, Constitutional Design without Constitutional Moments: Lessons from Religiously Divided Societies, 49 Corn. Int. L.J. 227 (2016). 
Addressing constitutional questions makes one ask "what kind of a country are we, anyway?" In divided societies, asking that question produces nothing but trouble. Like some successful marriages that survive for years so long as partners don't talk openly and honestly about issues that divide them, split societies often do better by postponing or obfuscating the answers to foundational questions. Perhaps paradoxically, real constitutional maintenance under these circumstances requires not the pompous posturing of judges about fundamental values, but the slipperiness and pragmatism of politicians making backroom deals.

It follows that the arguments for and against written constitutions will turn in large part on the seriousness of the threat of disintegration. Precisely because those who believe that constitutions hold societies together have things backward, writing down constitutional commands will work better in societies that are already united and worse in societies where disintegration is a real threat.

What do these various qualifications mean for Jones' thesis. My expertise is in American constitutional law, and in this context, I think that his arguments are mostly on target. America has a deeply entrenched constitution enforced by unelected judges. Many of its constitutional structures are antiquated or unfair. Constitutional rhetoric and law have served to exacerbate political differences and distract attention from reasonable compromise that might sensibly respond to real conditions on the ground. These pathologies, in turn, have contributed to a general political culture where the nonconstitutional constraints and inhibitions that actually hold the country together have eroded. Anyone who supposes that a centuries old document safely preserved under glass in Philadelphia will save us from the impending crisis is badly misguided. 
But I am not an expert in the political culture of the United Kingdom, so I do not have an informed opinion about whether an integrated written constitution would produce similar problems there. Jones knows much more about this than I do, and I am prepared to defer to his expertise. It is a shame that he has not used that expertise to dig more deeply into the local facts that are necessary to answer the question he poses. He is right to identify worrying tendencies in all written constitutions, but wrong to have failed to do more to investigate whether those tendencies would predominate in the United Kingdom. Without such an investigation, outsiders like me should be sympathetic to but agnostic about his claim. 
